\title{
Mast Cell Sarcoma
}

National Cancer Institute

\section{Source}

National Cancer Institute. Mast Cell Sarcoma. NCI Thesaurus. Code C9348.

A rare entity characterized by localized but destructive growth of a tumor consisting of highly atypical, immature mast cells.(WHO, 2001) 